\title{
The Influence of Bureaucracy Apparatus' Behaviour to Service Quality of Land Certificate (Study at the Land Office of Majalengka, West Java)
}

\author{
Aceng Jarkasih \\ Faculty of Social and Political Sciences, Majalengka University, West Java, Indonesia \\ acengjarkasih@unma.ac.id
}

\begin{abstract}
This study aims to show the bureaucratic apparatus's behavior towards the quality of land certificate services and find new concepts about the bureaucratic apparatus's behavior. The methodology used in this research is the explanatory survey method, following the study's objectives, which will explain the relationship between variables, namely the behavior of bureaucratic officials to the quality of land certificate services. Based on the results of research and discussion of the influence of the behavior of bureaucratic officials on the quality of service certificates at the Land Office of Majalengka Regency, the following can be disclosed: 1) The behavior of bureaucratic officials is oriented towards the dimensions of justice, empathy, discipline, sensitivity, and responsibility. Significantly affects the quality of land certificate services; 2) The height bureaucratic behavior towards the quality of land certificate services is determined by the dimensions of Fairness, empathy, discipline, sensitivity, and responsibility. and 3) Furthermore, from the results of this research, it can be found and developed a new model that "Kharimah behavior" are words for the dimension of caring in providing public services.
\end{abstract}

Keywords

apparatus behavior, quality, service; land certificate

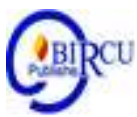

\section{Introduction}

The National Land Agency (BPN), apart from providing administrative services that are formal legality, also performs service functions that provide services and protection because by issuing land certificates. Therefore, the rights to the land of individuals/residents or communities/institutions and being guaranteed certainty of land rights and their land rights have been protected from other parties' interference. Conditions in Indonesia are still many cases related to status both in administrative and service systems. Organizational service problems occur a lot in community land errors, complaints are raised, and there are fluctuations in the community. It is necessary to overcome this problem; it is required to increase public services quality in the land sector and change the bureaucratic apparatus's mental attitudes and behavior so far. Services must have a friendly, responsive, and open service behavior in accepting complaints from the community, so it is hoped that the land sector's implementation can be carried out quickly, transparently, and reliably. To provide such fast, transparent, responsive, and reliable service, BPN (National Land Agency) is making various efforts, including another program currently being implemented known as the LARASITA (People's Service for Land Certification) program, which is presently expected to be an interaction between the government and the community, where the community is approached and can voice the problems that are accommodated to become input for BPN at a later date. Through this 
program, there will be an increase in public services quality in the land sector according to the community's expectations. However, in its implementation, the LARASITA program has not been implemented effectively and evenly in all district Land Offices, including the land office in Majalengka district, because some of the people of Majalengka do not understand and master information technology adequately so that they cannot access information through the LARASITA program provided by the government and the network to access in Majalengka Regency is a problem.

In addition to the conditions for achieving the reality of the quality of service expected from the bureaucracy, it has not displayed bureaucratic behavior as a public servant. The bureaucratic perspective tends to position the regulator as a servant, which will hinder service to the public. The case that occurred in Majalengka Regency was in the context of welcoming the BIJB Development. Land certification was one of the increasingly volatile public problems in the Majalengka community who immediately supported the local government, precisely according to its expectations. The disclosure of conflicts of interest to the surface and not yet having proof of control over land rights (land certificates) from most of the people of Majalengka is the main problem that must be the priority of the Majalengka Regency government, especially the Land Office to provide legal certainty in the land sector, to provide public service.

The existence of the land office of Majalengka district as a bureaucratic organization that is a vertical agency of the National Land Agency in the regions has the task of organizing governance in the land sector to provide quality services according to the wishes needs and supervision of the community. However, in reality, the quality service has not yet materialized what is expected. The behavior of the bureaucratic apparatus in the process of providing services to the community, which positions itself more as the person who commands and determines the services provided, giving rise to access to unofficial fees, collusion, and nepotism, to expedite the service, besides that due to the rigid behavior of the apparatus, and less friendly relations in service. This behavior is one of the causes for the low quality of service to the community. This shows that the bureaucratic apparatus has not provided the quality service that is expected by the community.

Meanwhile, quality service is an essential aspect of fostering public trust in the bureaucracy, unsatisfactory in providing services to the community. The problem is that the quality of land certificate services has not been maximized. One of the contributing factors is the attitude and behavior of bureaucratic officials who still emphasize their power rather than their services and tend to show behavior that they want to be served instead of serving because they feel needed by the community.

\section{Review of Literature}

According to Mayo in Hasibuan (2003: 177) states that:

"Human problems can only be accessed as a whole by using human data and tools. Morale or morale plays a more significant role and has a more substantial influence on workers' productivity. The moral is a condition that is closely related to one's mental condition. Good/fair treatment of employees has a more significant effect on large wages, even though wages are essential. "

The theory from the results of Mayo's research is also called the Theory of Human Sciences, views that humans are an essential element, which must be given space and movement on the importance of the feelings and attitudes of employees; therefore, efficiency must be supported by an understanding of human factors at work. Regarding individual behavior in organizations, human relations influence the smoothness of people's 
activities that can be applied in work situations and within the organization. As stated by Effendi (1986: 40-41) that the meaning of human relations emphasizes the spiritual process, which is aimed at satisfaction based on character, nature, temperament, behavior, etc., so that work behavior is directed towards a more productive direction. Such is the role of humans in behaving in public organizations, making behavioral analysis a fairly actual bureaucratic or government management approach. Studying human behavior individually, many of which receive contributions from the discipline of psychology, Robbin (2003: 14) states that "psychology is a science that seeks to measure, explain, and sometimes change human behavior." In addition to psychology, other fields contribute to Sigit's (2003: 1) behavioral behavior, such as sociology, social psychology, anthropology, and political science. Thus, these behavioral behaviors can be observed and developed again according to individual behavior, group behavior, and organizational behavior. The limits of understanding on each of these behaviors, these behaviors, Rivai (2003: 190-264) detail as follows:

"Individual behavior as a function of individual interactions with the environment, group behavior is all activities carried out or more individuals that can influence and relate to each other to produce positive achievements for both long-term and personal growth. Organizational behavior is a science field that interacts interactions between people in organizations, including behavior, structures, and processes in organizations".

Efforts in building, shaping, or reconstructing behavior and opinions regarding universal laws or behavioral theories are a problem that is often debated among behavioral experts. Thought about the absence of a universal method of Winardi's statement (2004: 197-198) explained no universally agreed procedure that managers can use to change personality. Attitudes, perceptions, or learning patterns. Concerning the phenomenon of individual behavior in the bureaucracy that can give birth to the bureaucratic apparatus's behavior. Some things cannot be taken from individuals as bureaucrats, namely the perceptions, attitudes, motivations, and knowledge they have to carry out their functions, duties, and responsibilities in the framework of public services, where the behavior of the bureaucratic apparatus is an interaction between individuals in the organizational environment so that there is a reciprocal influence among them, where the interaction occurs in the bureaucratic structure following their duties and responsibilities as state servants and community servants characterized byways of functioning as individuals and bureaucratic people, according to Supriatna (1997: 108) that the approach to the behavior of bureaucratic apparatus today is to develop more quality, value, service, innovation, flexibility, customers, and community empowerment. This opinion looks more at the quality side of the bureaucratic function, with the interaction between people and the bureaucracy, which will run following the direction of the bureaucratic environment, which is also a place for an individual activity to take place along with its unique characteristics, all of which can reach the quality of public services. Understanding the figures involved in a bureaucracy is very necessary to comprehend an understanding of bureaucratic behavior. If the bureaucratic environment in which these individuals are different, it will result in other individual behavior. When an individual enters a bureaucratic structure, that individual also brings along unique characteristics in the form of abilities, hopes, traits, and attributes that are also their characteristics. Likewise, the bureaucracy is an environment in which individuals whose powers are manifested like the task, the payroll system, the control system, etc. Thoha (2002: 185) stated that "the bureaucratic apparatus's behavior is essentially an interaction of results between 
individuals and their organizations." The general model of bureaucratic apparatus behavior can be described as follows:

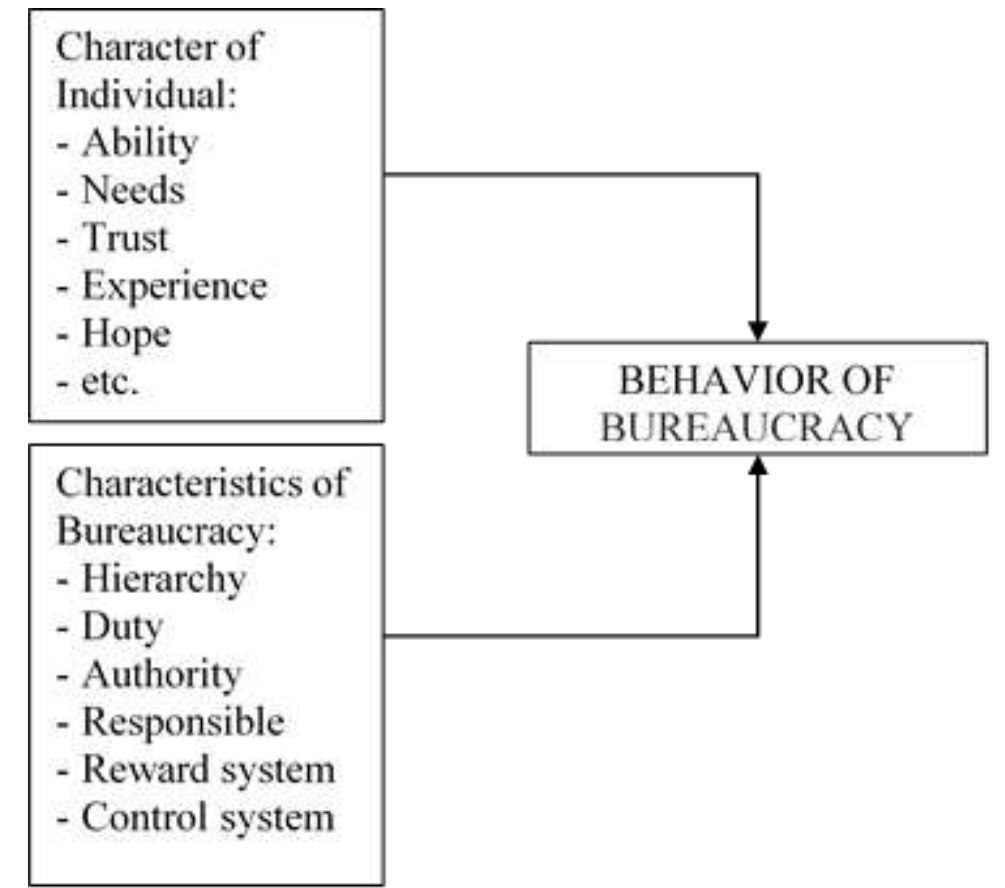

Figure 1. General Model of Bureaucratic Apparatus Behavior Source: Thoha (2002:185)

Every individual has different needs; even in an individual, the requirements are other from one time to another. Individuals bring into bureaucratic order abilities, personal beliefs, expectations, needs, experiences, etc. These are all individual characteristics, and these characteristics will enter a new environment, such as the bureaucracy. The bureaucracy used to rationalize the organization also has its features: hierarchy, task, authority, responsibility, reward, and control system. If individual characteristics interact with the bureaucracy's aspects, then the bureaucratic apparatus's behavior will arise. The need for an understanding of bureaucratic behavior is because bureaucracy is dynamic and changing. In these changing conditions, the people in the bureaucracy must adjust their behavior in these conditions.

\section{Research Methods}

This study uses an explanatory survey method following this study's objectives, which will explain the relationship between variables, namely bureaucratic officials' behavior, to the quality of land certificate services. This is as stated by Rusidi (1989: 177) that "as a consequence of the use of this research method, it is necessary to operationalize the variables which are more fundamental to their characteristics or indicators." The indicators of these variables indicate sufficient diversity of data and information in such away. The unit of analysis in this research is related to the bureaucratic apparatus's behavior at the Land Office and individual citizens of the Majalengka Regency community who have received land certificate services. To test bureaucratic behavior that significantly affected the quality of land certificate services at the Land Office of Majalengka Regency, data collection was carried out from 210 people who had obtained land certificate services from January to December 2011. Data collection was carried out using a questionnaire 
instrument that had tested its validity and reliability. After a descriptive analysis of the respondents' responses was carried out, the research hypothesis was tested. The analysis technique used by the author is structural equation modeling (SEM). Through the SEM technique, the writer can confirm the theory whether data support it or not. It is possible to carry out an analysis involving latent variables whose measurements are made through a series of indicators. SEM is a multivariate analysis technique that combines path analysis and factor analysis techniques. There are two models in SEM, namely the measurement model and the structural model. The measurement model is a model that explains the relationship between the latent variable and the observation variable. In contrast, the structural model is a model that describes the relationship between the latent variable and other latent variables.

The measurement model analysis provides information on which dimensions are most dominant in measuring the bureaucratic apparatus's behavior variables and the quality of land certificate services at the Land Office of Majalengka Regency. This information can be used as a reference to find out what the bureaucratic apparatus's behavior has been carried out concerning its impact on service quality. Furthermore, the structural model explains the significance of bureaucratic behavior on improving land certificate services' rate at the Land Office of Majalengka Regency and its influence. In this study, each dimension is represented by several items to obtain the dimension score that will be input in LISREL, and factor analysis is first carried out. The stages in the discussion of the first structural equation modeling (SEM) model are 1) multivariate normality test, 2) estimating the research model, 3) testing the overall model, 4) analyzing the measurement model, 5) analyzing the structural model and 6) calculating the size of the influence between variables.

\section{Results and Discussion}

Several problems have occurred in connection with land certification in the Majalengka Regency, which is thought to impact certification problems and inadequate administrative systems. Efforts are needed to improve the quality of public servants in the land sector through changes in mental attitudes and behavior of bureaucratic apparatus, which are arrogant and feel in power, become friendly, responsive, and willing to accept people's complaints, so that it can be expected that the service delivery in the land sector can be done quickly, transparently, and reliably. There is a temporary assumption that the bureaucratic apparatus's behavior has an essential role in improving the quality of services. A bureaucracy with a fair, caring, disciplined, sensitive, and responsible character is a bureaucracy that is expected to solve various problems in land certification by improving the service quality.

The findings of research conducted at the Land Office of Majalengka Regency show that other exciting and dilemmatic factors affect the not optimal quality of land certificate services when analyzed more deeply due to the mutual influence and interaction between the two internal and external factors. In this analysis, it can be seen that inline the research is carried out on two variables, namely the variable of the behavior of the bureaucratic apparatus and the quality of the land certificate service where external factors include historical, political, and economic factors. This study identifies environmental variables that contribute to the bureaucratic apparatus's behavior in the office/land office of Majalengka Regency from external aspects. As it is known, public bureaucracy never operates in space but always in specific environments where historical, economic, and political backgrounds become environmental variables that will influence the bureaucratic 
apparatus's behavior in providing land certificate services. Meanwhile, the internal factor in question is that the apparatus as a member of the bureaucracy has its own and unique characteristics as an individual being.

These external factors seem to interact with the characteristics of the internal aspects of the bureaucracy, which ultimately shape the behavior of the public bureaucratic apparatus, which tends to be power-oriented, which results in the death of care, attention, and the end of the personality of the bureaucratic apparatus so that it ignores the interests of service users and is very rigid in carrying out procedures and regulations thus lowering land certificate services. From the above explanation, it can be seen that one of the factors that influence the low level of land certificate services and which determines the services needed by the community is the Adi Kuasa factor who feels that "I am in charge so that the face of bureaucracy in the eyes of the community is reflected in the Personal Bureaucracy (powerful individuals) as mentioned. above "I am in charge and determine the wants and needs of society." The face of the bureaucracy in the public's eyes should not be a Bureaucracy with a personality full of moral values that can nurture and serve the community. Concerning human behavior, history provides valuable lessons for humans. Concerning a Concern whose existence is still questionable and at the same time has become a phenomenal problem to this day. The injustice and indifference that still occurs today in human life is an inseparable link from the history of human behavior. As the current reality, both expressly appearing on the surface that we can perceive by our five senses and implied by the various fluctuations we feel that do not appear on the surface, are described as multiple events of injustice, namely enmity, slavery, oppression, and struggle for power and luxury and all. This is to fulfill the human passions that will never be satisfied and end during his life. This injustice incident shows the loss of caring human nature with moral values towards God, Nature, and fellow humans. Then there was human destruction on this earth due to the act and hands of humans themselves.

The description of this event indicates the erosion of moral values that exist in humans and at the same time suggests the importance of sound ethical/moral values to form commendable human behavior regardless of the positive and negative effects of environmental factors, both the social, cultural, economic and environmental factors. Politics states that human behavior will be maintained. Through this kharimah behavior, justice, care, discipline, sensitivity, and responsibility can be upheld and enhanced. The kharimah behavior is in the attitude practice from the dimensions of honesty, trustworthiness, and responsiveness. Against the situation and environmental conditions faced. Based on the description above, the writer tries to build a Karimah Model behavior through a systems approach which can be described as follows: 


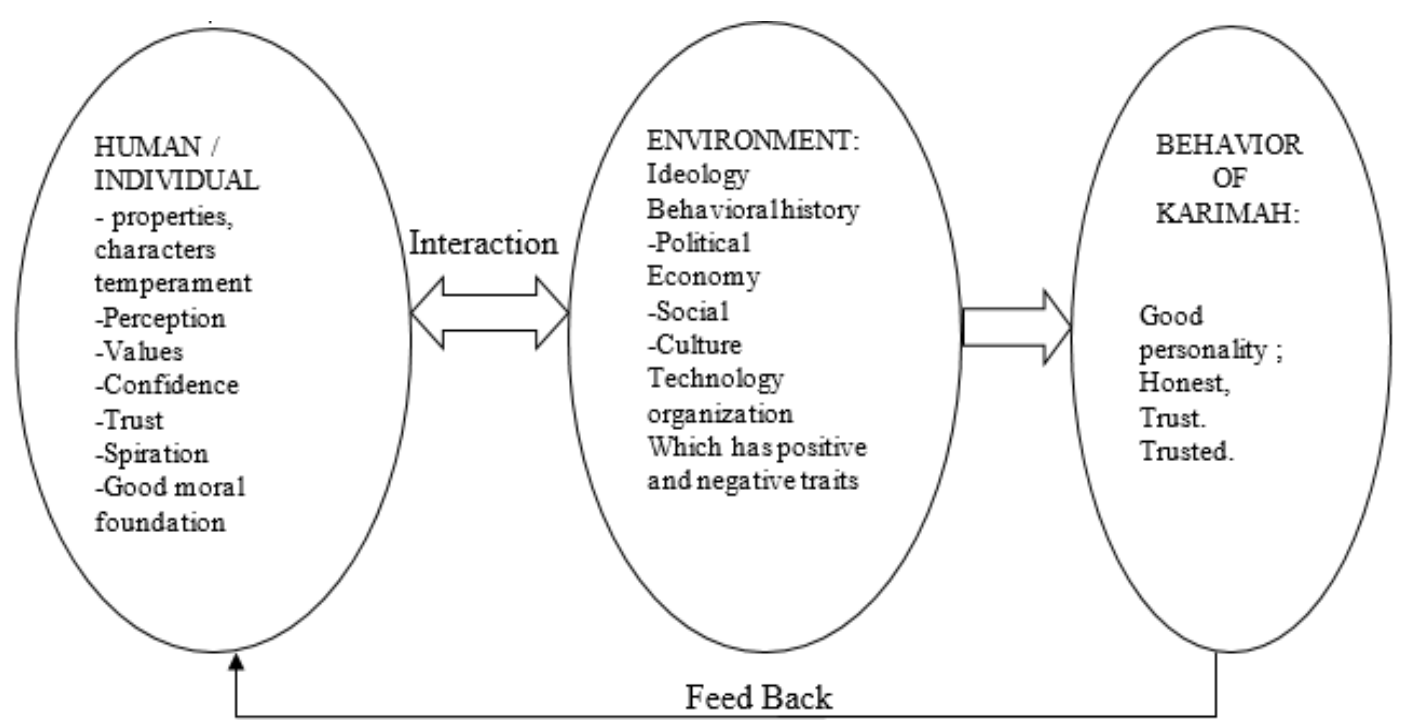

Figure 2. Karimah Behavior Model

The social behavior model illustrates that the interaction between humans determines social/commendable behavior (Out-put) as individuals (Input) and the environment (Process). Where humans as individuals who have traits, characters. Temperament, perception. Values, beliefs, and beliefs are based on moral values, interacting with environmental factors (ideology, political economy, social, culture, organization, and technology), which always have positive and negative sides of these ecological factors. Keep awake his behavior as a human who has a good personality. This, as stated by Lewin in Thoha (2002: 184), is formulated as follows: "Personality $=\mathrm{f}$ (heredity, experience) or personality is a function of innate nature and environment (experience)." Concerning the bureaucratic apparatus's behavior, it is hoped that this friendly behavior can answer the phenomenon of problems in the bureaucracy in public services. Furthermore, Saifullah (2000: 8) states that:

"To improve the quality of public services, the bureaucratic apparatus must have a spirit of service (a spirit of public services) and become a partner of society or collaborate with the community (top production). This requires behavior, among others, through the civilization of a code of ethics based on environmental support and translated into a standard of conduct that is generally accepted and used as a reference for officials' behavior at the central and regional levels. Besides, the government apparatus and system must be open and accountable."

On the other hand, paternalism's culture is still firm, which tends to encourage bureaucratic officials to be more power-oriented than service-oriented, position themselves as rulers, and treat service users as objects of service who need their help. Besides, the low quality of service is also caused by the power-sharing system, which tends to focus on the leadership of the hierarchical, bureaucratic structure encouraging the concentration of power and authority at the superiors so that bureaucratic officials who are directly related to service users often do not have sufficient control to respond to the developing dynamics, in providing services. Bureaucratic officials do not dare to develop creativity and innovation in service delivery so that public service activities. The absence of an appropriate incentive system, which can encourage bureaucratic officials to be efficient, responsive, and more minor professional of the apparatus, is also one factor that contributes to the poor performance of bureaucratic services. The bureaucratic apparatus's behavior is still far from being expected from the internal factors, such as bureaucratic accountability, which is still very low, as indicated by the neglect of service users' interests 
in providing land certificate services. Improvisation and discretion to respond to the dynamics, needs, and aspirations of service users are still rare in the public bureaucracy's life. It tends to be very small and insignificant.

The same thing happened to the bureaucratic sensitivity factor. The ability of the bureaucracy to complain about complaints from service users is still in the excellent category. The number of service users' complaints regarding land certificate services implementation shows the bureaucracy's low responsiveness. In some areas at the time of the research, there were many community complaints regarding land certificate services' performance. But the complaint was not immediately responded to with concrete actions regarding problems related to service users. Most of them tend to want to, which makes land certificate users disappointed and dissatisfied with the services they receive. This is complicated because service personnel who serve services do not focus on providing services because they have to carry out many other activities that are not related to their responsible services. In addition to serving the public who uses services, bureaucratic officials still have to do other tasks, such as fieldwork, which is often remarkably high. This results in bureaucratic officials often having to leave their duties to carry out different functions that are sometimes not their primary duties. As a result, many service users then have to wait for the officers, which takes quite a long time. Frequent officers leave the service to do other work and make services show that the public bureaucracy has not put interests into the essential part of their work. This, of course, will impact the image of the bureaucracy on services to the community.

Another perspective, especially history, it can be seen that the low performance of the bureaucracy, in this case, services to the community, especially land certificate services at the Land Office in Indonesia, can be implemented because from the background and orders of the bureaucracy both during the kingdom, colonialism and the New Order era were to serve power. In the kingdom era, the royal bureaucracy was formed to serve the king and his family's needs, not to serve the people's needs. The bureaucracy is the servant of the king, not the servant of the people; therefore, the orientation is not how to serve and prosper the people but to serve and prosper the king and his family, who are the rulers. (Dwiyanto et al., 2000: 15). This orientation towards the rulers of authority did not change much when the colonialists took power. It could increase because the colonial government tried to use the bureaucracy as a tool to defend its power and interests. The Dutch colonial government attempted to introduce changes and values of the modern bureaucracy. Still, all of this was done to make it easier for them to exercise control over the colony and its people. These changes were not carried out to bring the colonial government bureaucracy to pay attention to its people's needs and aspirations. From the New Order regime to the present, the rulers' orientation is still influential in the public bureaucracy's life. The values and symbols used in the bureaucracy are still firm, showing how the public bureaucracy and its officials describe themselves more as rulers as servants and servants of society. A single government as the title for regents and governors in the New Order era clearly shows how its officials' public bureaucracy at that time portrayed itself. Although the term is no longer used often today, the attitudes and behavior of bureaucratic officials who often position themselves as rulers have not changed much.

The firm culture of paternalism in bureaucratic life also worsens bureaucratic services. The culture of paternalism seems to be a fertilizer that contributes to the cultivation of various diseases in the bureaucracy's life. The power orientation and selfdescription as a ruler get justification from the values and symbols produced by the culture of paternalism. Bureaucratic officials often place service users not as sovereign citizens or as customers but as clients who need their help and assistance. Bureaucratic officials' 
orientation towards services is shallow, and service users' fair treatment in providing services is complicated. Situations like this are exacerbated by social realities, which often offer a higher environment for bureaucratic officials in people's lives. Bureaucratic officials find a kind and friendly place that has a higher social status than the average person. Social reality like this participates in providing assurance. The self-description of bureaucratic officials is more as a ruler as a servant and a public service. It can be implemented if-then bureaucratic officials often treat service users indifferently, do not care about service users' interests, even make them as service objects that can be played according to their interests. The imbalance in regulating the rights and obligations of service users and service providers makes the functions of service users very weak when dealing with bureaucratic officials. Bureaucratic officials can mistreat service users without service users being able to protest their actions.

The unsatisfactory service of land certificates is also due to the absence of good service ethics and can be used by bureaucratic officials to provide good public services. Values such as equality and professionalism that should be the basis for developing service ethics are still very far from the practice of public service delivery. As a result, discrimination and unfair and arbitrary treatment in administration, land certificate services are still easily found in the Land Office of Majalengka Regency. From the explanation above, it can be seen that the problem of the behavior of the bureaucratic apparatus in improving public services is very complex. Efforts to improve the behavior of the bureaucratic and service apparatus require a strong commitment within themselves to keep trying to be fair, caring, disciplined, sensitive, and responsible, all of which are a mandate that must be carried out correctly as a form of dedication to the community, the State and God and the existence of community support as well as control over the implementation of public services. Based on the five dimensions of bureaucratic behavior analysis, the lowest performance according to users' view of land certificate services is the dimension of care with a total score of $(62.3 \%)$. Whereas in the measurement of land certificate services, responsiveness is considered low, with a total score of (57.4\%). This phenomenon further strengthens the previous suspicion that bureaucratic officials' behavior has not reflected the community's expected behavior in providing land certificate services. This is related to the lack of responsiveness of the bureaucratic apparatus to the community's problems and complaints in land certificate services, which raises public dissatisfaction with these services. This is further emphasized by their lack of care and bureaucratic apparatus when providing land certificate services. They do not feel the needs and conditions that the community uses land certificate services. Therefore bureaucracy tends to be rigid in delivering services, except because there are kinship relations, closeness or "extra costs" or orders from superiors and magic letters. The stiffness and selfish attitude will wear off deeply with a friendly, timely, and flexible attitude. Therefore, in line with various development changes in the Majalengka district to welcome the construction of an International Airport, a fairer, caring, disciplined, sensitive, and responsible bureaucratic behavior is vital to improve service quality due to current regulations and developments. In the community, especially in Majalengka Regency.

The renewal strategy is essential considering that so far, the bureaucracy has entered the grip of specific political forces so that it forgets its primary mission as a public servant during global change and the challenge of requiring the bureaucratic apparatus to carry out internal reforms at the level of structure, procedure, culture, and figures. This significant change was a disaster caused by democratization, decentralization, and a difference in the development paradigm that was no longer top-down but bottom-up. The desired pattern of relations now is broader public interaction from private elements society, academic 
elements in universities, and the government itself in policy formulation and policy implementation. It is known as good governance in which accountability, openness, and democratization become the guide. There are three main dimensions in any organizational theory that cannot be ignored, and the three dimensions are technical dimensions, dimensional concepts, and human dimensions. If these three dimensions can be considered, it will give birth to an effective organization. The technological dimension of the skills needed to move the organization. The dimension contains bureaucratic expertise in technical fields that can drive the organization, for example, computer expertise, marketing, engineering, and others. The second dimension is the concept of dimension, which is the first dimension's driving force and is very close to the third dimension, namely the human dimension. According to Mustofa et al in Sriono et al (2021) The growth of information needs on land that is more accessible that is demanded by the public (policy recipients) and the government (policy makers) is increasing higher than before. Purba in Isnaini et al (2020) stated that In general, the term "policy" used to designate the behavior of an actor (for example an official, a group, as well as a government agency) or a number of actors in a particular area of activity. The term policy is distinguished from the word wisdom meaning wisdom or wisdom. Policy is a general statement of behavior than organization.

Suppose the bureaucracy at work only relies on the first dimension and ignores the second dimension or even neglects the third dimension. In that case, it will create a climate that is not respectful of the organization's main supporting factors, namely humans. The science of organizational behavior reduces bureaucracy's disrespectful attitude by drawing part of its view centered on human behavior itself as the third dimension in an organization. Besides, it can be seen from the public administration approach that behavior is not optimal. The bureaucratic apparatus in providing quality land certificate services to the Majalengka Regency people is caused by several things, namely: lack of socialization, funding, monitoring, and evaluation, and complaints. Program socialization is one of the keys to a program's success, including the LARASITA program, which is currently at the forefront of direct services to the community regarding land certificate services that have not been implemented optimally. A review of existing documents at the Land Office and field visits concluded that outreach to the community about the LARASITA program, which relies on disseminating informal information from village officials and officers, is one of the program's weak points. In general, the community and beneficiaries did not receive comprehensive program information. Many of them do not know available information, such as the meaning of LARASITA. This illustrates that the bureaucracy's performance to provide quality services, especially land certificate services, has not run as expected. Therefore, Siagian's (1994: 91) theory states that the behavior of bureaucratic apparatus which is fair, caring, disciplined, sensitive, and responsible has been tested to affect the quality of public services with dimensions of reliability, responsiveness, empathy belief, and tangibility (Zeithaml, 1990;24). the bureaucracy apparatus at the Majalengka Regency Land Office has not been optimally implemented.

\section{Conclusion}

The bureaucratic apparatus's behavior is oriented towards the dimensions of justice: care, discipline, sensitivity, and responsibility. Significantly affects the quality of land certificate services. In other words, the behavior of the bureaucratic apparatus dramatically determines the quality of land certificate services. This means that the better the bureaucratic apparatus's behavior, the better the service quality of land certificates. The 
magnitude of the influence of bureaucratic behavior on land certificate services' quality is determined by the dimensions of Fairness, care, discipline, sensitivity, and responsibility. Of the five dimensions, the dimension of care is the lowest dimension that has not been appropriately implemented, which is closely related to the behavior of the bureaucratic apparatus, so that this dimension has a vital role in explaining the effect of bureaucratic behavior on the quality of land certificate services compared to the other five dimensions. Furthermore, from the results of this research, it can be found and developed a new concept/model that "Kharimah Behavior" is a branch for the dimension of care in providing public services. In other words, Kharimah's behavior contains good personality values in direct contact with service users to offer land certificate services. In other words, the higher one's charity behavior, the higher the level of one's care in providing services to the community. The quality of service will increase if an apparatus's good personality values support it in carrying out its service duties.

\section{References}

Berge, L. Bruce. 1989. Qualitative Research Methods. USA: Allyn and Bacon.

Burn, JP. 1994. Assian Civil Service System: Improving Efficiency and Productivity. Times Academic Press. Singapore.

Caiden E.Gerald (ed). 1982. Strategies For Administrative Reform. Lexington Books: Toronto.

Cooper, J. Phillip (ed). 1998. Public Administration For The Twenty First Century. USA: Harcourt Brace College Publishers.

Cushway, Berry \& Derek Lodge. 2002. Organizational Behavior and Design. Perilaku dan Desain Organisasi, Struktur-Pekerjaan \& Peran Komunikasi-Motivasi(cetakan ketiga), (Terjamahan Sularno Tjiptowardojo), Jakarta: Gramedia.

Dunn, William.1994. Public Policy Analysis: An Introduction. A. Simons and Schuster Company, Englewood Cliff : Prentice Hall.

Ferdinand, Agusty. 2002. SEM dalam Penelitian Manajemen. Semarang: BP-UNDIP.

Ferlie, dkk, 1996, The New Public Management in Action, Oxford University Press, New York.

Fitzimmons, James A. dan Mona, Fitzimmons,J. 2001. Service Management: Operation, Strategy and Information Technology, International Edition. New York: Mc.GrawHill

Gartson, David and Debra Steward. 1983 Organization Behaviour and Public Management. Marcell Dekker Inc.New York.

Gore,Al. 1994. Putting Customers First Common Sense Government, Work Better And Cost Less. New York: The Third Report Of The National Performance Review.

Greenberg, Jerald dan Robert A. Baron. 1997. Behaviour in Organization, Understanding and Managing The Human Side of Work. New Jersey,Prentice-Hall Inc.

Harmon, Michael and Richard T,Mayer. 1986. Organization Theory for Public Administration. Little Brown and Co. Toronto.

Hersey, Paul. \& Ken Blanchard.1977. Management of Organizational Behaviour: Utilizing Human Resources, Prentice Hall. New Delhi.

Isnaini, et al. (2020). The Models of North Sumatra Provincial Government Policy in Resolving the Ex-Hgu Land Conflicts of PTPN II Plantations in Deli Serdang Regency. Budapest International Research and Critics Institute-Journal (BIRCIJournal), Volume 3, No 2, Page: 1206-1215. 
Kotler, Philip. 1994. Marketing Management,Analysis, Planning,Implementation and Control, Prentice Hall International.Eight Edition.

LAN RI, 2003. Pedoman Standar Pelayanan Publik. Jakarta : PKP2AI-LAN

Lenvine,Charles H., B.Guy Peters dan Frank J.Thomson. 1990. Public Administration; Chalenge, Choices, Consequences. Illinois: Scott Foremans little,Brown Higher Education.

Loffter, Elke. 1996. Modernization of The Public Sector in on International Comparative Perspective: Concept and Methods Of Awarding And Assesing Quality In The Public Sector. Auflalge : Speyer.

Lovelock, Christopher. 1994. Product Plus, How Product + Service Competitive Advantage, Mac Graw-Hill, Inc.

Minzberg, Henry. 1983. Structure in Five Designing Effective in Organizations. New Jersey : Prentice Hall.

Mosher, Frederich.1968. Democracy and The Public Services. Oxford University Press. New York.

Neuman, W.Laurence. 1997. Social Research Methods, Qualitative and Quantitative Approaches. Third Edition. Allyn and Bacon.

Osborne, David \& Plastrik. 1997. Banishing Bureaucracy. The Five Strategies for Reinventing Government. New York : Addison-Wesley Publishing Company,Inc.

Osborne, David and Ted Gaebler. 1992. Reinventing Government: How The Entrepreneurrian Spirit Is Transforming The Public Sector.New Cork : Pluma Penguin Publish Group.

Rohdewohld, Rainer. 1995, Public Administration in Indonesia. Australia: Montech PTY LTD.

Rosenbloom, David H. and Robert S Kravchuk. Public Administration, Understanding Management,Politics, and Law in the Public Sector. Sixth Edition. New York :The McGraw-Hill Companies,Inc.

Southerland, J.W.(Ed).1986. Management Hand Book of Public Administrator. Van Nostrand Reinhold Company. New York.

Spenser, Lyle M.JR. \& Signe M. Spenser.1993. Competence at Work. Models for Superrior Performance. John Willey \& Sons Inc.

Sriono, et al. (2021). Legality of Execution of Collateral Based on Electronic Mortgage Certificate in Bank Credit Agreement. Budapest International Research and Critics Institute-Journal (BIRCI-Journal), Volume 4, No 1, Page 15-27.

Stillman II, Richard J, 1984. Public Administration : Concepts and Cases, Boston : Houghton Miffin Company.

Tjiptono, Fandi dan Anastasia Diana, 2003. Total Quality Management (Edisi Revisi). Yogyakarta : Andi.

Tjiptono, Fandi, Gregorius Chandra. 2005. Service, Quality. Satisfaction. Yogyakarta : Andi.

Umar, Husein. 2001. Strategic Management in Action. Jakarta : Gramedia Pustaka Utama. 